\title{
Using estimated yearly progression rates to compare radiographic data across recent randomised controlled trials in rheumatoid arthritis
}

\author{
V Strand, R Landéwé, D van der Heijde
}

Ann Rheum Dis 2002;61 (Suppl II):ii64-ii66

$T$ his review is based on publications and presented abstracts from six randomised controlled trials (RCTs) in the treatment of rheumatoid arthritis assessing treatment effects on radiographic measures of disease progression. Each used the Sharp scoring method to assess changes in erosions and joint space narrowing from baseline. ${ }^{1-3}$ These RCTs showed that the newly approved synthetic and biological disease modifying antirheumatic drugs, leflunomide, infliximab, etanercept, and Anakinra, were effective, and confirmed the efficacy of sulfasalazine and methotrexate in retarding disease progression. $^{4-13}$ Provided that sample sizes are adequate, randomisation within a protocol accounts for the heterogeneity of disease populations and yields linear progression rates over time. ${ }^{14}$

Each RCT enrolled a unique patient group with significantly different demographics and baseline disease characteristics across the trials, although well balanced within each protocol. Because of these population differences it is not appropriate to compare directly changes in total composite (Sharp) scores across trials. However, it is possible to compare the data if one uses an estimate of yearly progression of radiographic damage, based on prior progression, where patients have continued to receive previous treatment, or were untreated. This is obtained by dividing mean baseline composite scores for each treatment group by the mean reported disease duration (table 1). ${ }^{15} 16$ This value can be used as a "benchmark," allowing rough numerical comparisons to observed change scores, but should not be used for statistical comparisons. Estimated progression rates are, of course, only estimates, limited by errors in dates of disease onset, and are less valid in patients with disease durations of $\leqslant 1$ year. Table 1 illustrates that, despite certain common baseline demographics and disease characteristics, each protocol population in these recent RCTs had a unique estimated yearly progression rate.

All trials used the composite scoring method; the European interleukin 1 receptor antagonist (ILRa) monotherapy RCT included $x$ rays of the hands and not the feet. ${ }^{17}{ }^{18}$ When comparing data across trials, these differences do not appear to be important because observed progression rates in all active treatment groups seem similar and numerically much less than estimated yearly progression rates. Mean changes in composite scores in the placebo treatment groups in three of the four recent RCTs met or exceeded estimated yearly progression rates for the trial groups, with one exception, the "Utilization of Leflunomide for the Treatment of Rheumatoid Arthritis" (ULTRA or US 301 trial), where $63 \%$ of patients initially assigned to placebo received active treatment for a mean of 7-8 months when 12 month follow up radiographs were performed. ${ }^{4}$ Table 2 illustrates the good agreement between estimated yearly progression rates and observed change scores in placebo treatment groups in four RCTs including the leflunomide, methotrexate, and sulfasalazine comparisons, respectively (US 301 and MN 301), "Anti-Tumor Necrosis Factor Trial in Rheumatoid Arthritis with Concomitant Therapy" (ATTRACT), and European ILIRa monotherapy trials. This indicates that the estimated yearly progression rate at baseline may be useful when comparing radiographic data across RCTs.

In general, radiographic responses are poorly correlated with clinical improvements by American College of Rheumatology (ACR) response criteria or disease activity score, C reactive protein (CRP), or measures of physical function. ${ }^{19}{ }^{20} \mathrm{In}$ longitudinal series, it is not until patients have $8-15$ years of disease that we see correlations between evidence of radiographic damage and loss of physical function. ${ }^{21}$

Estimated yearly progression rates also best predict radiographic progression over $2-5$ years of continued active treatment in the COBRA trial, when the two treatment groups

Abbreviations: CRP, C reactive protein; ILIRa, interleukin 1 receptor antagonist; RCTs, randomised controlled trials

\begin{tabular}{|c|c|c|c|c|c|c|}
\hline Variable & US $301^{47}$ & $M N 301^{57}$ & $M N 302^{56}$ & ATTRACT $^{9}$ & ERA 1013 & European ILI $\mathrm{Ra}^{11} 12$ \\
\hline Total No of patients & 482 & 356 & 985 & 428 & 632 & 472 \\
\hline No in each treatment group & $118-182$ & $91-134$ & $487-495$ & $81-88$ & $207-217$ & $116-121$ \\
\hline Mean age (years) & $53-55$ & $55-59$ & 58 & $51-54$ & $49-51$ & $52-54$ \\
\hline Mean disease duration (years) & $6.5-7.0$ & $5.7-7.6$ & $3.7-3.8$ & $9.2-11.6$ & $\leqslant 1.0$ & $3.7-4.3$ \\
\hline$\leqslant 2$ Years' disease duration (\%) & $33-40$ & $38-45$ & $43-44$ & $9-23^{*}$ & 100 & NR \\
\hline Mean DMARDs failed & $0.8-0.9$ & $0.8-1.0$ & 1.1 & 3.0 & $0.5-0.6$ & NR \\
\hline DMARD naive (\%) & $40-45$ & $40-53$ & $33-34$ & 0 & $54-61$ & 19-34 \\
\hline Baseline HAQ-DI & 1.3 & $1.7-1.9$ & 1.5 & $1.7-1.8$ & $1.4-1.5$ & $1.5-1.6$ \\
\hline Baseline composite $x$ ray scores & $22.8-25.4$ & $41.9-46.3$ & $24.6-24.9$ & $66.6-81.9$ & $11.2-12.9$ & $24.7-29.6$ \\
\hline Estimated yearly progression & $3.3-3.7 \dagger$ & $5.7-8.1 \dagger$ & $6.5-6.7 \dagger$ & $6.4-8.0 \dagger$ & 8.0-9.0†‡ & $6.3-7.4 \dagger$ \\
\hline
\end{tabular}

RF, rheumatoid factor; DMARDs, disease modifying antirheumatic drugs; CRP, C reactive protein; HAQ-DI, Health Assessment Questionnaire disease index; NR, not reported.

*\% Of patients with $\leqslant 3$ years' disease duration; †calculated from mean of baseline total Sharp scores divided by mean disease duration for each treatment group; $\ddagger$ may be overestimated owing to mean disease duration of $\leqslant 1$ year. 
Table 2 Estimated yearly progression rates $v$ observed changes in placebo treatment groups

\begin{tabular}{|c|c|c|c|c|}
\hline Variable & US $301^{7}$ & MN $301^{7}$ & ATTRACT ${ }^{9}$ & $\begin{array}{l}\text { European } \\
\text { ILI Ra' }\end{array}$ \\
\hline Mean disease duration (years) & 6.9 & 5.7 & 10.9 & 3.7 \\
\hline Baseline total composite score & 25.4 & 46.2 & 81.9 & 27.4 \\
\hline Estimated 6 or 12 month progression rates at baseline & 3.7 & $8.2^{*}$ & 7.7 & $7.4^{*}$ \\
\hline $\begin{array}{l}\text { Observed yearly progression rates in placebo groups } \\
\text { over } 6 \text { or } 12 \text { months }\end{array}$ & 2.2 & $11.8 *$ & 7.0 & $7.0^{*}$ \\
\hline
\end{tabular}

were divided into tertiles according to estimated yearly progression rates at baseline. ${ }^{22}$ Medians and interquartile ranges of change in $x$ ray scores over $2-5$ years in the second and third tertiles in the sulfasalazine group, and in the third tertile in the COBRA group, were higher than in the first, indicating a continued benefit from treatment on radiographic progression with combination therapy (web extra fig Wl). In the ATTRACT trial, progression over two years in the

\section{US 3012 year cohort-baseline to year 2}

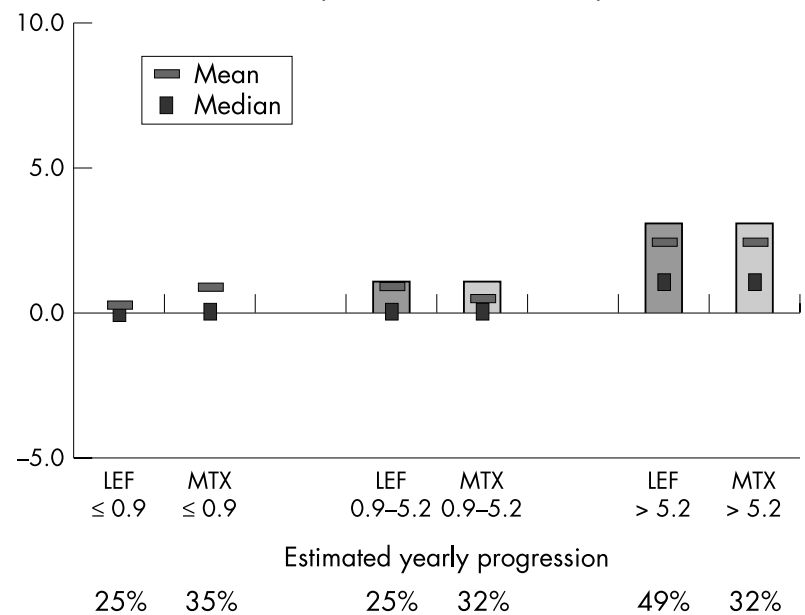

Figure 1 US 301 two year cohort (baseline to year 2).

Mean/median, interquartile ranges by tertiles of estimated yearly progression at baseline. LEF, leflunomide; MTX, methotrexate.

MN 302/4 2 year cohort-baseline to year 2

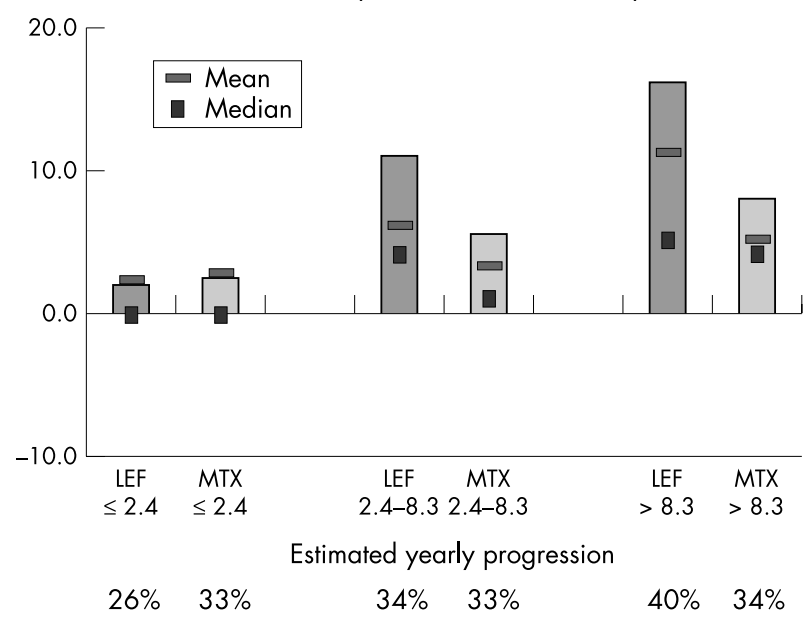

Figure 2 MN 302/4 two year cohort (baseline to year 2). Mean/median, interquartile ranges by tertiles of estimated yearly progression at baseline. Percentages represent the distribution of patients in each tertile in the year 2 cohort. LEF, leflunomide; MTX methotrexate. infliximab + methotrexate groups combined showed medians of 0 across all three tertiles, compared with progressively higher median scores in each tertile in the placebo + methotrexate treatment group, again demonstrating the persistent benefit of combination therapy. ${ }^{23}$ Similar differences in progression in the leflunomide and methotrexate groups in US 301 and MN 302/4 are evident over two years of treatment, with more progression in the third tertiles than first, and higher values in the protocol with the earlier disease group (MN 302/4) (figs 1 and 2). ${ }^{64}$ Estimated rates of yearly progression at baseline, rather than rheumatoid factor, CRP, or other disease characteristics best predicted further damage.

In conclusion, sample sizes in recent RCTs have been sufficient to demonstrate linear radiographic progression rates over 2-5 years of continued treatment. Each protocol population is unique, with a unique estimated yearly radiographic progression rate. These estimated rates can serve as a "benchmark" to facilitate comparisons across RCTs, to allow better comparison of treatment associated effects in the absence of a placebo control, and better prediction of those patients who can be expected to most benefit from treatment.

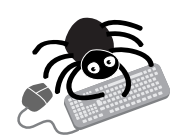

Results of the COBRA trial can be seen at www.annrheumdis.com

\section{Authors' affiliations}

V Strand, Stanford University, Division of Immunology, Palo Alto, CA, USA

R Landéwé, D van der Heiide, Department of Internal Medicine, Division of Rheumatology, University Hospital Maastricht, Maastricht, The Netherlands.

Correspondence to: Dr V Strand, 306 Ramona Road, Portola Valley, CA 94028, USA; vstrand@aol.com

\section{REFERENCES}

1 Sharp JT, Lidsky MD, Collins LS, Moreland J. Methods of scoring the progression of radiologic changes in rheumatoid arthritis: correlation of radiologic, clinical and laboratory abnormalities. Arthritis Rheum $1971 ; 14: 706-20$.

2 Sharp JT. Scoring radiographic abnormalities in rheumatoid arthritis. Radiol Clin North Am 1966;34:233.

3 van der Heijde DM, van Leeuwen MA, van Riel PL, van de Putte LB. Radiographic progression of radiographs of the hands and feet during the first 3 years of rheumatoid arthritis measured according to Sharp's method (van der Heijde modification). J Rheumatol 1995;22:1792-6.

4 Strand V, Cohen S, Schiff M, Weaver A, Fleischmann R, Cannon G, et al. Treatment of active rheumatoid arthritis with leflunomide compared with placebo and methotrexate. Arch Intern Med 1999;159:2542-50.

5 Smolen JS, Kalden JR, Scott DL, Bozman B, Kvien TK, Larsen A, et al. Efficacy and safety of leflunomide compared with placebo and sulphasalazine in active rheumatoid arthritis: a double-blind, randomised, multicentre trial. Lancet 1999;353:259-66.

6 Emery P, Breedveld FC, Lemmel EM, Kaltwasser JP, Dawes PT, Gomor B, et al. A comparison of the efficacy and safety of leflunomide and methotrexate for the treatment of rheumatoid arthritis. Rheumatology (Oxford) 2000;39:655-65. 
7 Sharp JT Strand V, Leung H, Hurley F, Loew-Friedrich I. Treatment with leflunomide slows radiographic progression of rheumatoid arthritis: results from three randomized controlled trials of leflunomide in patients with active rheumatoid arthritis. Arthritis Rheum 2000;43:495-505.

8 Scott DL, Smolen JS, Kalden JR, van de Putte LBA, Larsen A, Kvien TK, et al. Treatment of active rheumatoid arthritis with leflunomide: two year follow up of a double blind placebo controlled trial versus sulfasalazine. Ann Rheum Dis 2001;60:913-23.

9 Lipsky PE, van der Heijde DMFM, St Clair EW, Furst DE, Breedveld FC, Kalden JR, et al. Infliximab and methotrexate in the treatment of rheumatoid arthritis. N Engl J Med 2000;343:1594-602.

10 Bathon JM, Martin RW, Fleischmann RM, Tesser JR, Schiff MH, Keystone $E C$, et al. A comparison of etanercept and methotrexate in patients with early rheumatoid arthritis. N Engl J Med 2000;343:1586-93

11 Bresnihan B, Alvaro-Gracia JM, Cobby M, Doherty M, Domliian Z, Emery $P$, et al. Treatment of rheumatoid arthritis with recombinant human interleukin-1 receptor antagonist. Arthritis Rheum 1998;41:2196-204.

12 Jiang Y, Genant HK, Watt I, Cobby M, Bresnihan B, Aitchison R, et al. A multicenter, double-blind, dose-ranging, randomized, placebo-controlled study of recombinant human interleukin-1 receptor antagonist in patients with rheumatoid arthritis: radiologic progression and correlation of Genant and Larsen scores. Arthritis Rheum 2000;43:1001-9.

13 Genovese M, Bathon J, Martin R, Fleischmann R, Tesser JR, Schiff MH, et al. Etanercept vs methotrexate in patients with early rheumatoid arthritis (ERA trial): two year radiographic and clinical outcomes. Arthritis Rheum 2002;46: 1443-50.

14 Sharp JT, Wolfe F, Corbett M, Isomaki H, Mitchell DM, Furst DE, et al. Radiological progression in rheumatoid arthritis: how many patients are required in a treatment trial to test disease modification? Ann Rheum Dis $1993 ; 52: 332-7$
15 Strand V Sharp JT. Radiographic data from recent RCTs in RA: what have we learned? Arthritis Rheum (in press).

16 Wolfe F, Strand V. Radiography of rheumatoid arthritis in the time of increasing drug effectiveness. Curr Rheumatol Rep 2001;3:46-52.

17 van der Heiide D. How to read radiographs according to the Sharp/van der Heijde method. J Rheumatol 1999;26:743-5.

18 Strand V, Lassere M, van der Heijde D, Johnson K, Boers M. Recent rheumatoid arthritis clinical trials using radiographic endpoints - updated research agenda. J Rheumatol 2001;28:887-9.

19 Boers M. Demonstration of response in rheumatoid arthritis patients who are nonresponders according to the ACR $20 \%$ criteria: the paradox of beneficial treatment effects in nonresponders in the ATTRACT trial. Arthritis Rheum 2001;44:2703-4.

20 Keystone E, Han C, Keenan GF, van der Heijde D, Harriman G. Infliximab plus methotrexate prevents structural damage progression in rheumatoid arthritis patients independent of clinical response [abstract] Arthritis Rheum 2001;44:S81.

21 Scott DL, Pugner K, Kaarela K, Doyle DV, Woolf A, Holmes J, et al. The inks between joint damage and disability in rheumatoid arthritis. Rheumatology (Oxford) 2000;39:122-32.

22 Landewe RB, van der Heijde D, Verhoven A, Boonen A, Boers M, van der Linden S. Radiological progression rate at baseline predicts treatment differences: results from the COBRA trial [abstract]. Arthritis Rheum 2001;44:S371.

23 van der Heijde D, Landewe RB, Lipsky PE, Maini RN. Radiological progression rate at baseline predicts treatment differences: results from the ATTRACT trial [abstract]. Arthritis Rheum 2001;44:S80

24 Cohen S, Cannon G, Schiff M, Weaver A, Fox R, Olsen N, et al for ULTRA trial investigators group, Strand V. Two year treatment of active rheumatoid arthritis with leflunomide compared with methotrexate. Arthritis Rheum 2001:44:1984-92. 